\title{
Investigation of Aquifer Zone in Tambakromo Village, Ponjong Subdistrict, Gunung Kidul Regency, Yogyakarta, Indonesia
}

\author{
Al Hussein Flowers Rizqi ${ }^{1}$, Oky Sugarbo ${ }^{2}$ \\ Institut Teknologi Nasional Yogyakarta, Indonesia ${ }^{1,2}$ \\ alhussein@sttnas.ac.id ${ }^{1}$, okysugarbo@itny.ac.id ${ }^{2}$ \\ Received: December $5^{\text {th }}, 2020$. Revised: March $12^{\text {th }}, 2021$. Accepted: March $25^{\text {th }}, 2021$
}

\section{Keywords :}

Tambakromo; Aquifer; Semilir Formation; Geolectrical;

Schlumberger

\begin{abstract}
The presence of surface water is always being a primary issue in Gunung Kidul regency. An aquifer investigation would support groundwater exploration. The research area is located in Tambakromo village, Ponjong subdistrict, Gunung Kidul Regency, Daerah Istimewa Yogyakarta Province. The aim of this research is about geological and subsurface conditions based on geological data and geoelectrical resistivity methods. By resistivity value interpretation, the position, depth, and thickness of aquifer could be determined. The purpose of this research is to identification of geological conditions that supported being aquifer rock. The method in this research is used geological mapping combined with petrographic analysis. The geophysics method is used to identification of aquifer in research area. Three locations were selected to acquisition geoelectrical resistivity survey. In Grogol village, there is no aquifer based on resistivity values of more than 10000 ohmmeters (andesitic breccia). An akuifuge is interpreted there in andesitic breccia instead of the presence of aquifer. The tuffaceous is interpreted as lapillistone that contained the glass with resistivity value of 43.63 and 340.11 ohmmeters. The Garon and Sumberejo village have aquifer at depth of 50 to 80 meters with a thickness of 13 to 70 meters. The type of aquifer in both area is included an unconfined aquifer, specifically located in between the limestone rock layer and andesitic breccia. By regional stratigraphic correlation, tuffaceous lapillistone is interpreted as derived from Semilir Formation. In addition, the presence of aquifer in research area could recommend for local people and government to reduce the drought disaster.
\end{abstract}

\section{INTRODUCTION}

Gunung Kidul is one area that included in emergency drought status [1]. This area has a big part of infertile soil and its surrounded by karst hills that has a rainfall rate of 115 days in a year [2]. The 
presence of surface water is always being a primary issue in Gunung Kidul. In 2019, the presence of dolines has been a drought for supply the water storage for daily activities such as drinking, showering, and feeding [3].

The surface water storage in Gunung Kidul is supported by geological and subsurface condition. Geologically, a big part of southern part of Gunung Kidul Regency consists of Wonosari Formation that comprised of limestone, tuffaceous marl limestone, tuffaceous sandstone and siltstone [4] (Fig. 1). The surface soil in this area is a dry land that rare of surface water in spite of the water resource is available for underground river [5]. Aquifer condition in Gunung Kidul is controlled by geology and hydrology system [6]. The minimum depth of aquifer is 150 meters and maximum depth at 175 meters. The maximum thickness of aquifer is about 40 to 50 meters [7].

The research area is located in Tambakromo village, Ponjong sub district, Gunung Kidul Regency, Special Region of Yogyakarta Province that geologically consisted of limestone and those the reasons why this area is interested to study. Based on aquifer flow system, the research area is divided into two groups such as intergranular aquifer and porous aquifer system due to rocks leaching [8]. The forming of groundwater or aquifer generally is supported by some factors such as rock physical properties, in this case, is primary porosity and structural geology that could be secondary aquifer. Secondary aquifer formed in structural geology zone with an impermeable rock layer [9]. Ponjong subdistrict was selected to be research area due to one of 10 sub district that included in drought area in June, 2019 [10]. In addition, the rainfall was low rate during Mei to September in the last 10 years [11]. Based on all the conditions in research area, the surface exploration and groundwater exploitation are needed for daily clean water need.

The object of this research is the determination of geological and subsurface conditions based on geological data and geoelectrical resistivity method. The geoelectric resistivity method is one of the geophysical methods used to estimate the subsurface as the main object [12]. Based on resistivity value interpretation, the position, depth, and thickness of aquifer could be determined. The purpose of this research is to identification of geological condition that supported for being aquifer rock [13]. In addition, the subsurface condition condition would be represented in 1 D / 2D modeling of lithology section. The presence of aquifer in research area could give a recommendation for local people and government to reduce the drought disaster.

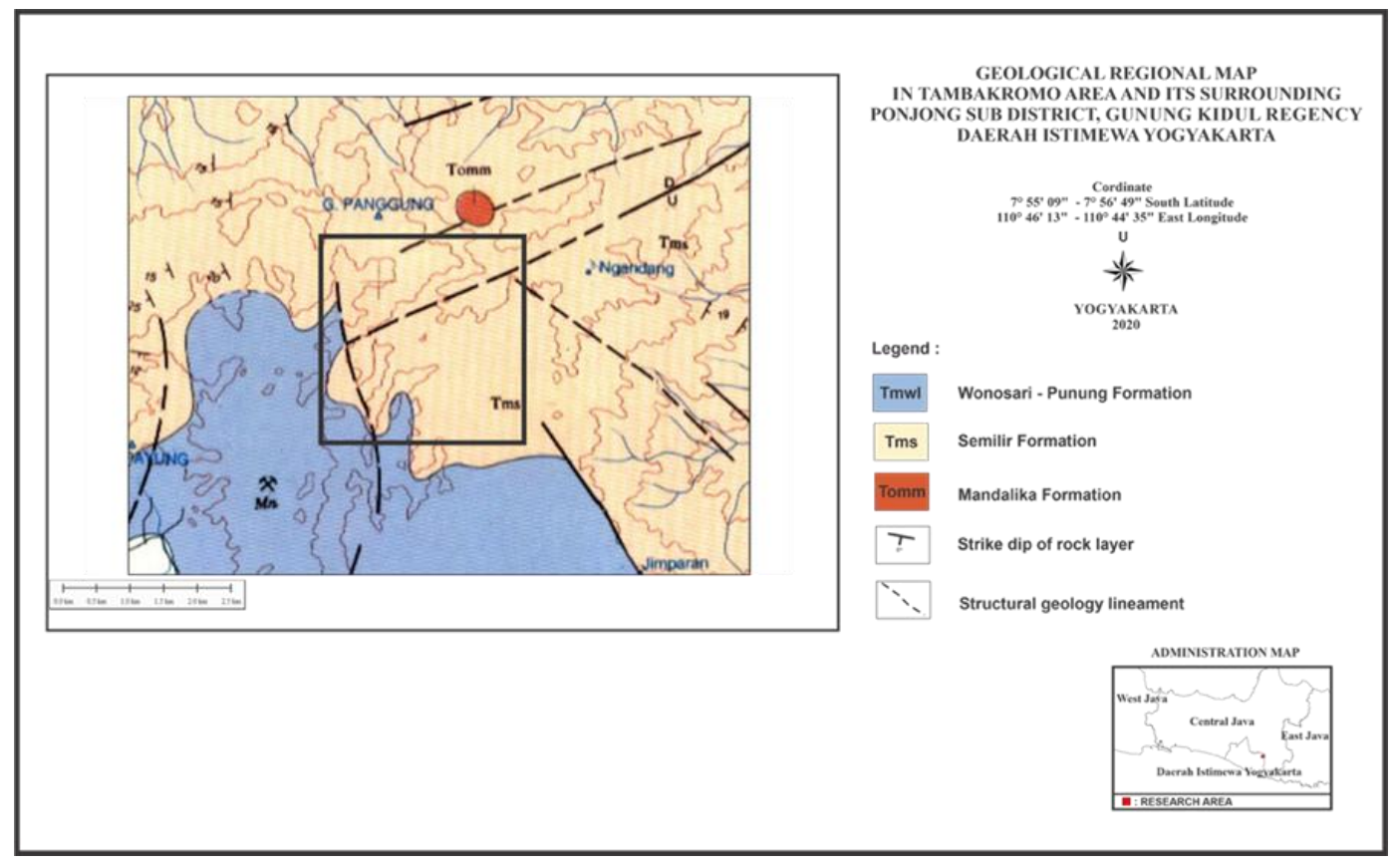

Fig 1. Regional Map of Research Area 


\section{METHOD}

Some authors have studied in Ponjong Sub district, Gunung Kidul regency for some topics. Geological condition consists of Semilir Formation and Wonosari Formation also granulometric analysis of sand deposited in Tambakromo area is derived from Mandalika Formation [14]. Aquifer in Sawah Ombo village, Ponjong has a depth of 68 meters with resistivity value 1.58 ohmmeter [15].

The next step is field observation by geological mapping and acquisition of geolectrical resistivity with Schlumberger configuration (Fig.2). Geological mapping conducted to geomorphology, lithology, structural geology (fractures and faults), and springs. The geolectrical resistivity survey used the resistivitymeter to measuring the rock resistivity with Schlumberger configuration. This geoelectrical resistivity array was on the flat land along 250 meters with the electric current power.

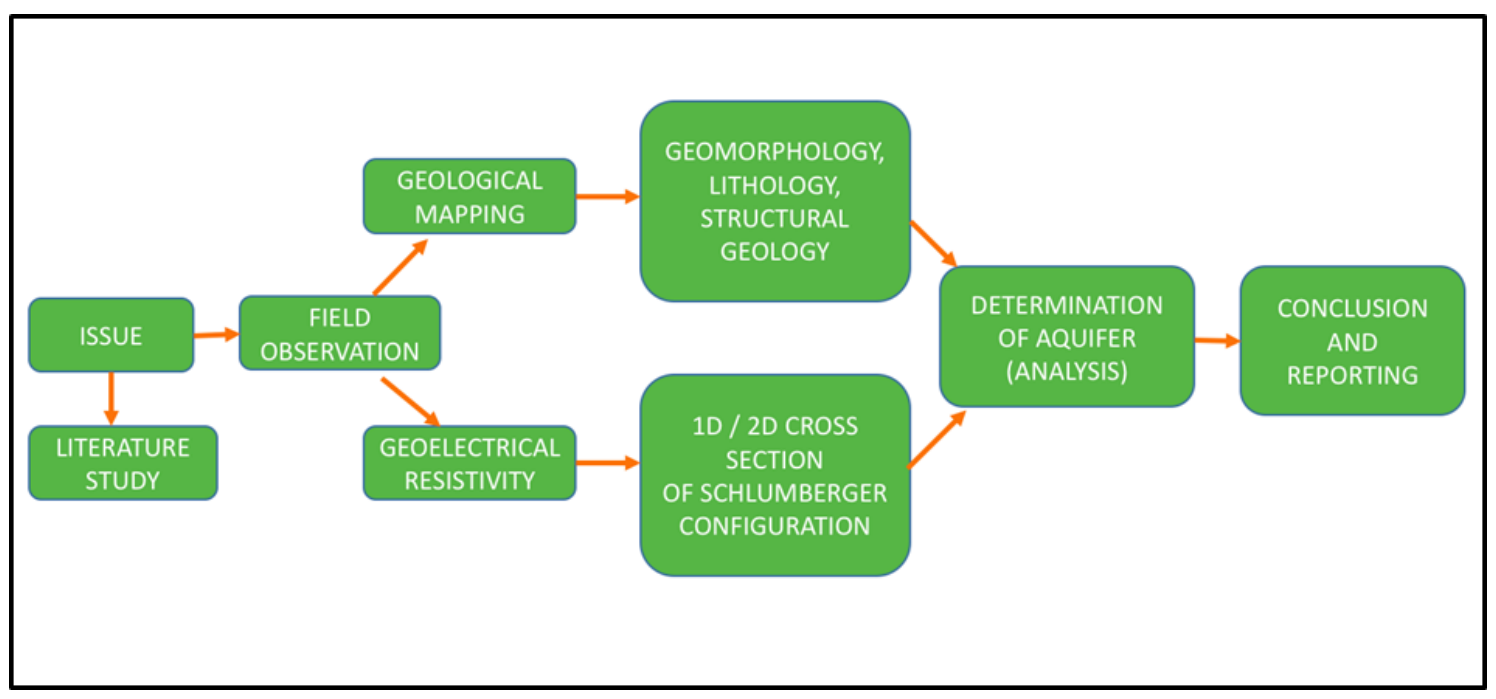

Fig 2. Research Method Flow Chart

Studio analysis conducted the data processing of geological and geoelectric resistivity used the software. Geological software such as Arc Gis, Microsoft Office, Microsoft Excel is used to make a topography map, geomorphological map, and geological map. The geophysical software such as Progress 3.0 is used to process the rock resistivity value. The final processing of this software would give information about the rock variation vertically in a lithology column. By this lithology column, the depth and thickness of aquifer zone would be determined exactly through interpretation of rock resistivity value [16]. Studio analysis is also conducted to petrographic analysis that supports to rock description in detail composition.

Interpretation and data evaluation is step that conducted the compilation of surface and subsurface data comprehensively. Integration data from laboratory such as petrographic analysis and then combined to subsurface (resistivity data). Interpretation of rock formation based on both rock name of petrographic data and resistivity value would be correlated with geological map and regional stratigraphy. Distribution of aquifer could be viewed from correlation of stratigraphy or lithology column. By viewing of lithology column and its correlation, the potential of aquifer rock layer would be determined exactly.

\section{RESULTS AND DISCUSSIONS}

The current study found that an investigation of aquifer zone in several places. Three villages were 
conducted in acquisition data of geoelectrical resisitivity such as Grogol Village, Garon Village, and Sumberejo Village.

\section{Grogol Village}

In this location, the resistivity geoelectrical acquisition is configured in 350 meters of electrodes array. There was spring around the data acquisition location. The subsurface condition could be interpreted by rock formation with the thickness of 270 meters (Fig 3). The lithology is formed by sediment deposit and massive andesitic breccia. Andesitic breccia is interpreted from resistivity value that more than $10.000 \mathrm{ohm}$ meters [16] (Table 1).

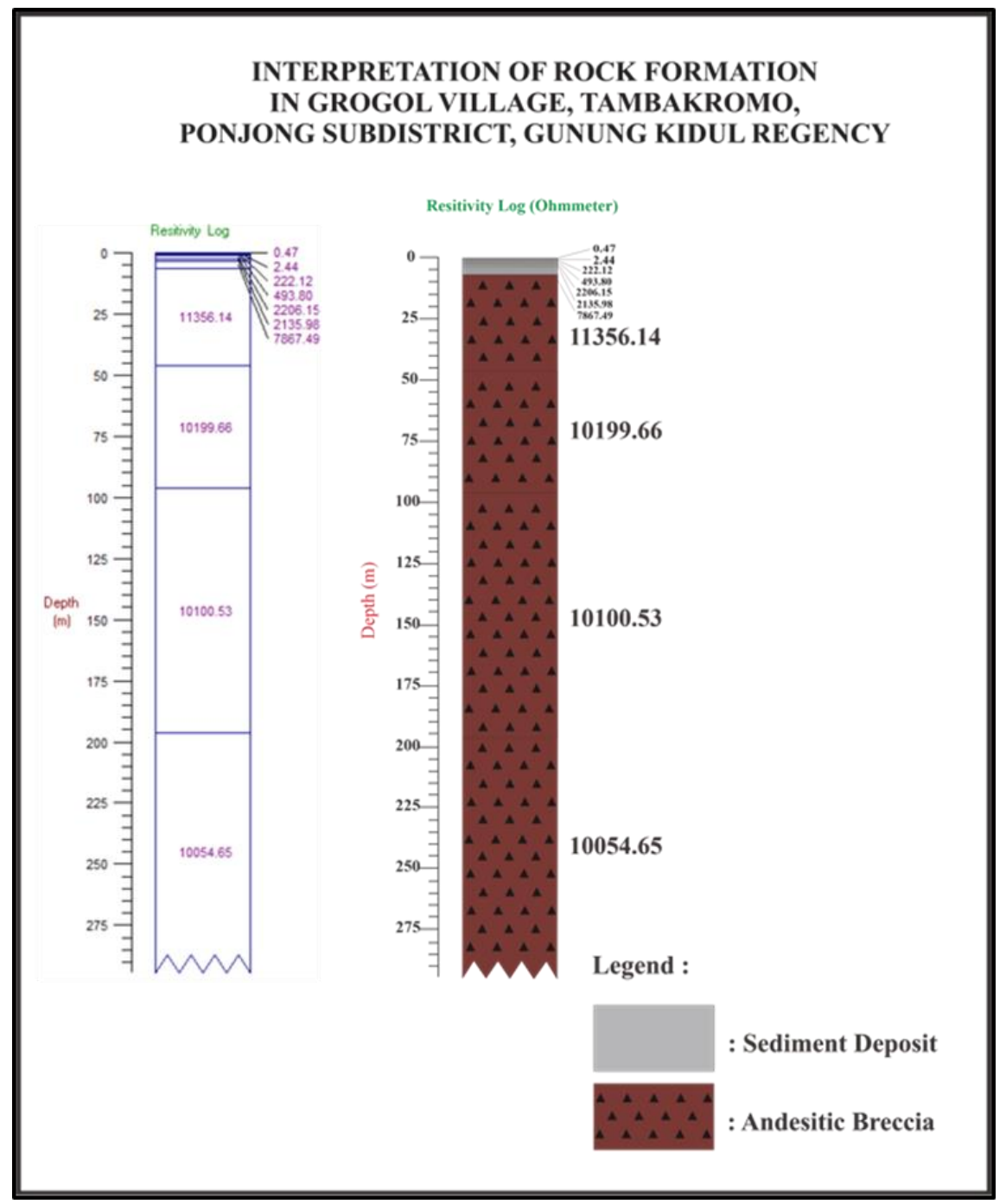

Fig 3. Lithology Column of Rock Formation and Resistivity Value in Grogol Village

Table 1. Interpretation of Rock Formation Based on Resistivity Value in Grogol Village

\begin{tabular}{cccc}
\hline $\begin{array}{c}\text { Depth } \\
\text { (meter) }\end{array}$ & $\begin{array}{c}\text { Thickness } \\
\text { (meter) }\end{array}$ & $\begin{array}{c}\text { Resistivity } \\
\text { (Ohm meter) }\end{array}$ & Lithology (rock name) \\
\hline $0-3$ & 3 & 0.47 to 7867.49 & Sediment deposit \\
\hline $3-48$ & 45 & 11356.14 & Andesitic breccia \\
\hline $48-95$ & 47 & 10199.66 & Andesitic breccia \\
\hline $95-195$ & 100 & 10100.53 & Andesitic breccia \\
\hline $195-275$ & 80 & 10054.65 & Andesitic breccia \\
\hline
\end{tabular}

Based on Table 1, the rock formation dominantly consists of andesitic breccia. Andesitic breccia is 
formed in Mandalika Formation [4]. Andesitic breccia is a volcanic rock that very hard, tight, and solid. There is no rock porosity or permeability unless if there some fractures inside the rock. However, the rock characterization of andesitic breccia is not supported to being an aquifer that could be water storage. Breccia is included in aquifuge [17] that could not preserve the groundwater or run off the water. In fact, at location of acquisition geoelectrical resistivity, there was a spring. This spring is interpreted as the result of the presence of several faults in research area.

\section{Garon Village}

The Garon village is located in the southwestern part of Grogol Village. In this location, the resistivity geoelectrical acquisition is configured in 350 meters of electrodes array. The total depth in this location reached 220 meters based on subsurface lithology interpretation (Fig. 4). The rock formation consists of sediment deposit, clay (weathered tuff / tuffaceous soil), bedded limestone, crystalline limestone, tuffaceous lapillistone, and andesitic breccia (Table 2).

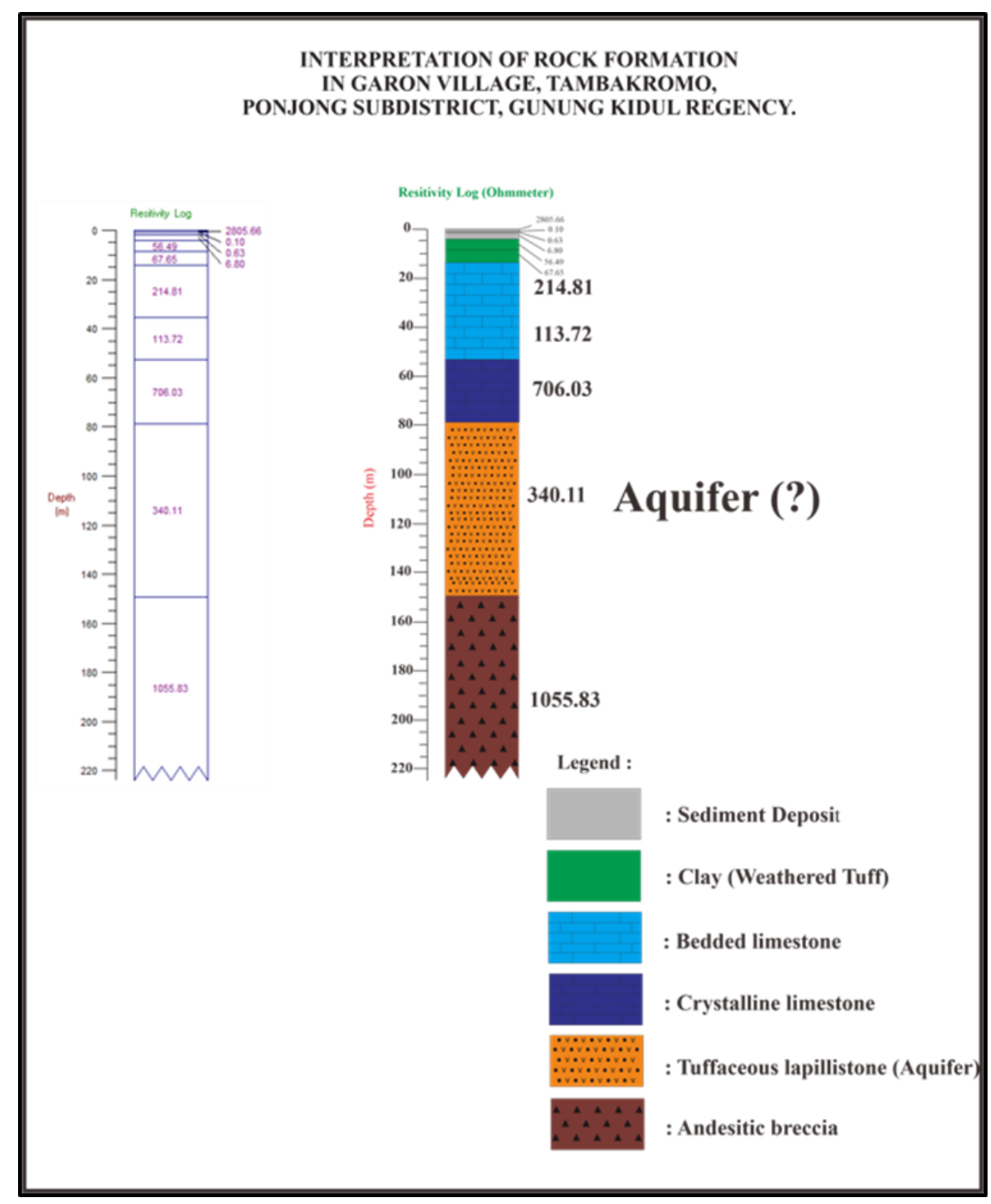

Fig 4. Interpretation of Rock Formation and Resistivity Value in Garon Village

The geological condition in Garon Village is more complex than Grogol Village, especially in rock formation. The rock formation is interpreted by resistivity value according to [16] On the surface to the depth of 4 meters, resistivity value from 0.1 to 2805.66 ohmmeter is interpreted as sediment deposit. The depth of 4 to 16 meters is interpreted as clay. This clay could be interpreted from weathered tuff) (Fig. 6). Bedded limestone could be interpreted from a resistivity value of 113.72 to 214.81 ohmmeter. Crystalline limestone is in resistivity value of 706.03 ohmmeter. Both bedded 
limestone and crystalline limestone are derived from Wonosari Formation [4].

The position of tuffaceous lapillistone is underneath Wonosari limestone. It could be interpreted from resistivity value of 340.11 ohmmeter and it included in Semilir Formation. This physical rock characteristic has moderate to well porosity for being an aquifer. In a petrographic analysis, the tuffaceous lapillistone (sample code of SMLR-03) is composed dominantly of volcanic glass (59.75\%), lithic (8,25\%), hornblende (1.5\%), feldspar (29.25\%), and opaque mineral (1.25\%), namely Crystall Tuff [18]. The rich in glass rock would be a good aquifer due to its ability to absorb the water.

The kind of aquifer in this area is a confined aquifer with a thickness of 70 meters. A confined aquifer is an aquifer that upper (crystalline limestone) and lower layer (andesitic breccia) boundaries are impermeable rock formations, the water level would appear above the lower stressed rock formation [19]. The aquifer could be reached at depth of 80 meters (deep aquifer).

Table 2. Interpretation of Rock Formation Based on Resistivity Value in Garon Village

\begin{tabular}{cccc}
\hline $\begin{array}{c}\text { Depth } \\
\text { (meter) }\end{array}$ & $\begin{array}{c}\text { Thickness } \\
\text { (meter) }\end{array}$ & $\begin{array}{c}\text { Resistivity } \\
\text { (Ohmmeter) }\end{array}$ & Lithology (rock name) \\
\hline $0-4$ & 4 & 0.1 to 2805.66 & Sediment deposit \\
\hline $4-16$ & 12 & 56.49 to 67.65 & clay (weathered tuff) \\
\hline $16-55$ & 39 & 113.72 to 214.81 & Bedded limestone \\
\hline $55-80$ & 25 & 706.03 & Crystalline limestone \\
\hline $80-150$ & 70 & 340.11 & $\begin{array}{c}\text { Tuffaceous lapillistone } \\
\text { (Aquifer) }\end{array}$ \\
\hline $150-220$ & 70 & 1055.83 & Andesitic breccia \\
\hline
\end{tabular}

The basement rock in this area is andesitic breccia with the resistivity value of 1055.83 ohmmeter. Andesitic breccia in Garon village has different resistivity value from andesitic in Grogol village. Both of them are aquifuge that could not preserve the groundwater.

\section{Sumberejo Village}

Sumberejo village is a western part of Garon and Grogol village, the acquisition data conducted in the valley. In this location, the resistivity geoelectrical acquisition is configured in 350 meters of electrodes array. The rock formation in this area consists of sediment deposit, clay (weathered tuff / tuffaceous soil), bedded limestone, tuffaceous lapillistone, and andesitic breccia (Fig. 6) (Table 3).

The sediment deposit was distributed over the area near to the acquisition data location. The sediment deposit is interpreted from resistivity value of 0.59 to 15.88 meters with thickness of 8 meters (Table 3 ). The altered clay is outcropped in this area with a greenish color (Fig. 7). Altered clay with a greenish color is interpreted as chlorite alteration indicating the propylitized zone [20]. This alteration is supported by the presence of a left strike slip fault in this area (Fig.8).

Alteration clay is interpreted from Mandalika Formation which is the oldest rock formation in research area. Mandalika Formation was represented by andesitic breccia tuff, and lava [6]. The clay altered is caused by the rock composition which is dominantly composed by feldspar. This alteration indicated the potential of mineralization in this research area.

Bedded limestone is interpreted by the resistivity value of 128.02 ohmmeter and thickness of 28 meters. It outcropped in the southern part of acquisition location at Sumberejo village. This limestone is derived from Wonosari Formation [4]. 
Investigation of Aquifer Zone in Tambakromo Village, Ponjong Subdistrict, Gunung Kidul Regency... Al Hussein Flowers Rizqi, Oky Sugarbo

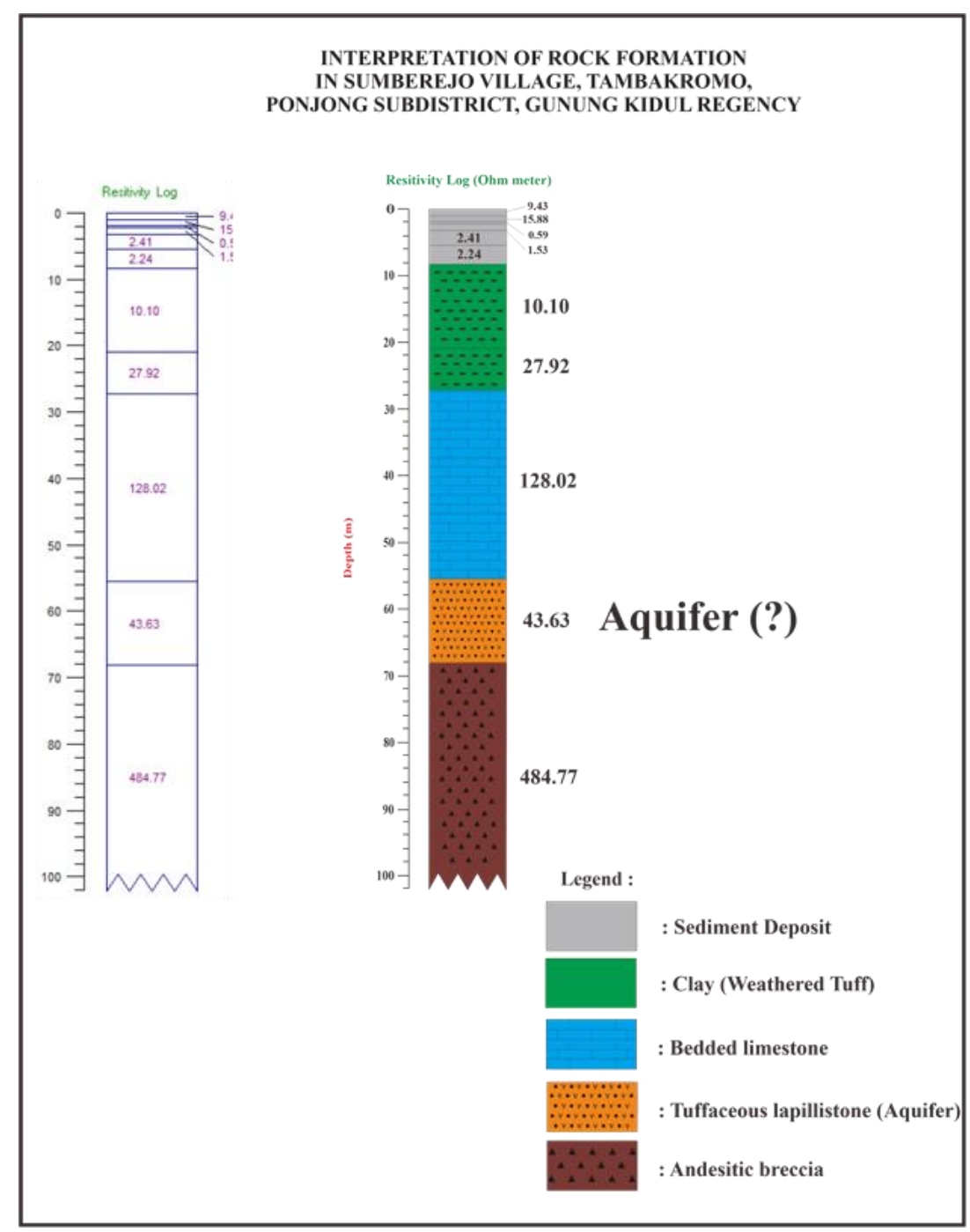

Fig 6. The Lithology of Rock Formation in Sumberejo Village

Table 3. Interpretation of Rock Formation Based on Resistivity Value in Sumberejo Village

\begin{tabular}{cccc}
\hline $\begin{array}{c}\text { Depth } \\
\text { (meter) }\end{array}$ & $\begin{array}{c}\text { Thickness } \\
\text { (meter) }\end{array}$ & $\begin{array}{c}\text { Resistivity } \\
\text { (Ohmmeter) }\end{array}$ & Lithology (rock name) \\
\hline $0-8$ & 8 & 0.59 to 15.88 & Sediment deposit \\
\hline $8-27$ & 19 & 10.10 to 27.92 & clay (weathered tuff) \\
\hline $27-55$ & 28 & 128.02 & Bedded limestone \\
\hline $55-68$ & 13 & 43.63 & $\begin{array}{c}\text { Tuffaceous lapillistone } \\
\text { (Aquifer) }\end{array}$ \\
\hline $68-100$ & 32 & 484.77 & Andesitic breccia \\
\hline
\end{tabular}

The position of tuffaceous lapillistone is underneath the Wonosari bedded limestone with resistivity value of $43.63 \mathrm{ohmmeter}$. This rock support to saving the groundwater due to its petrographic rock composition (sample code of SMLR-04) (Fig 8). The rock composed of lithic (12\%), hornblende $(1.5 \%)$, feldspar $(30.75 \%)$, and the biggest rock compositions of volcanic glass $(54.5 \%)$. By calculating those rock composition, the name of this rock is Crystall Tuff [18].

Volcanic glass has characteristics for adsorbing water in subsurface or surface water. In addition, volcanic glass in rock also can store water or aquifer. In this area, the aquifer could be reached at depth of 55 meters and it has a thickness of 13 meters including the deep aquifer. This aquifer is included in a confined aquifer with an upper layer and underlayer are impermeable rock. 


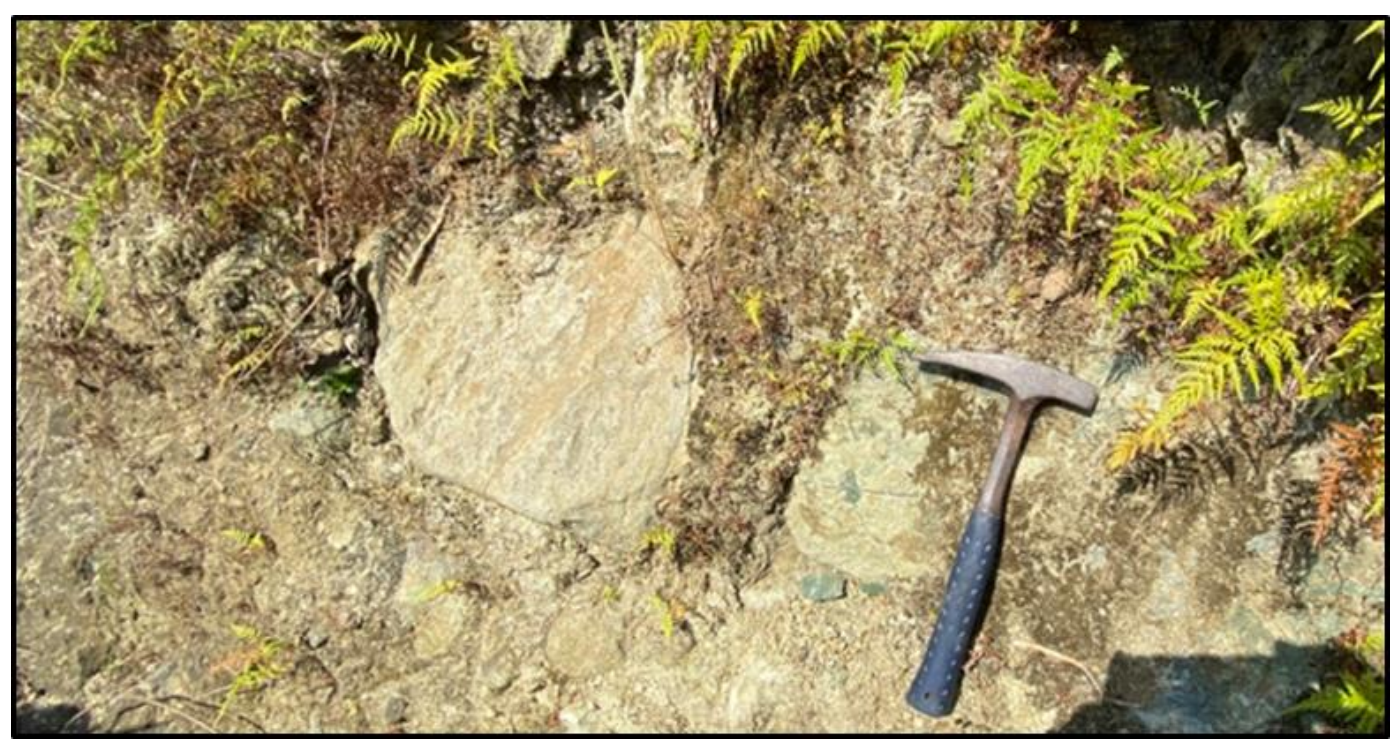

Fig 7. Altered Clay is Composed of Chlorite Mineral

The under layer of aquifer is andesitic breccia that is regionally stratigraphy derived from Mandalika Formation [14]. Andesitic breccia is also a basement rock in this area with a resistivity value of 484.77 ohmmeter. It also freshly outcropped along the river near to point of geoelectrical resistivity acquisition.

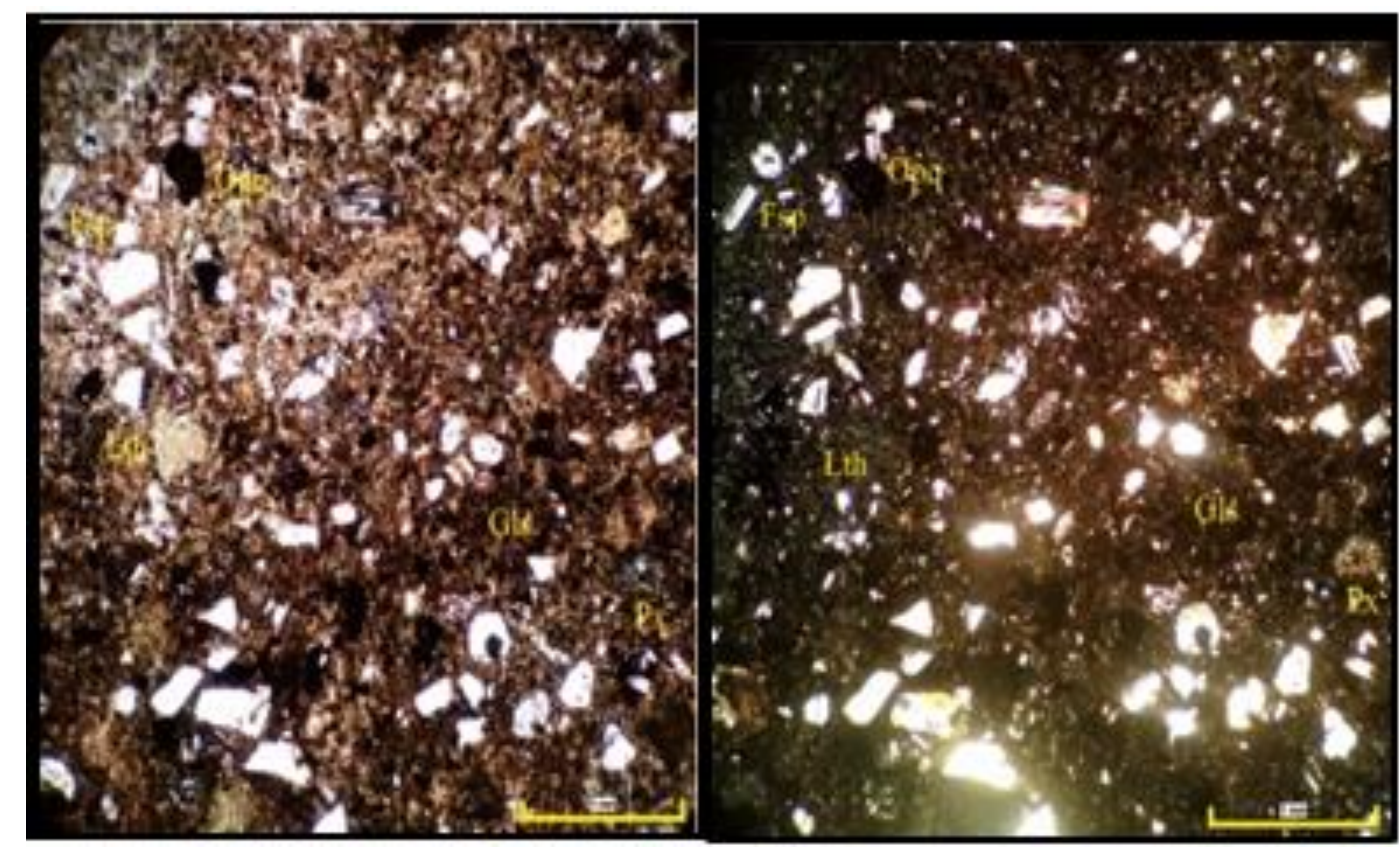

Fig 8. Photomicrograph of Crystall Tuff Dominantly Composed of Glass, PPL in Left Figure, XPL in Right Figure

The presence of aquifer in research area is also supported by the morphology in each geolectrical resistivity acquisition. The research area is included in discharge area with the water infiltration in the northern part area, it's the area around Panggung massive hill [21]. Panggung massive hill is included in recharge area due to its elevation approximately about 700 meters.

On other hand, the structural geology has triggered the presence of aquifer based on geological detail 
map of Tambakromo area (Fig. 9). Some fractures and faults worked as a pathway to water flow conducted as springs or aquifer.

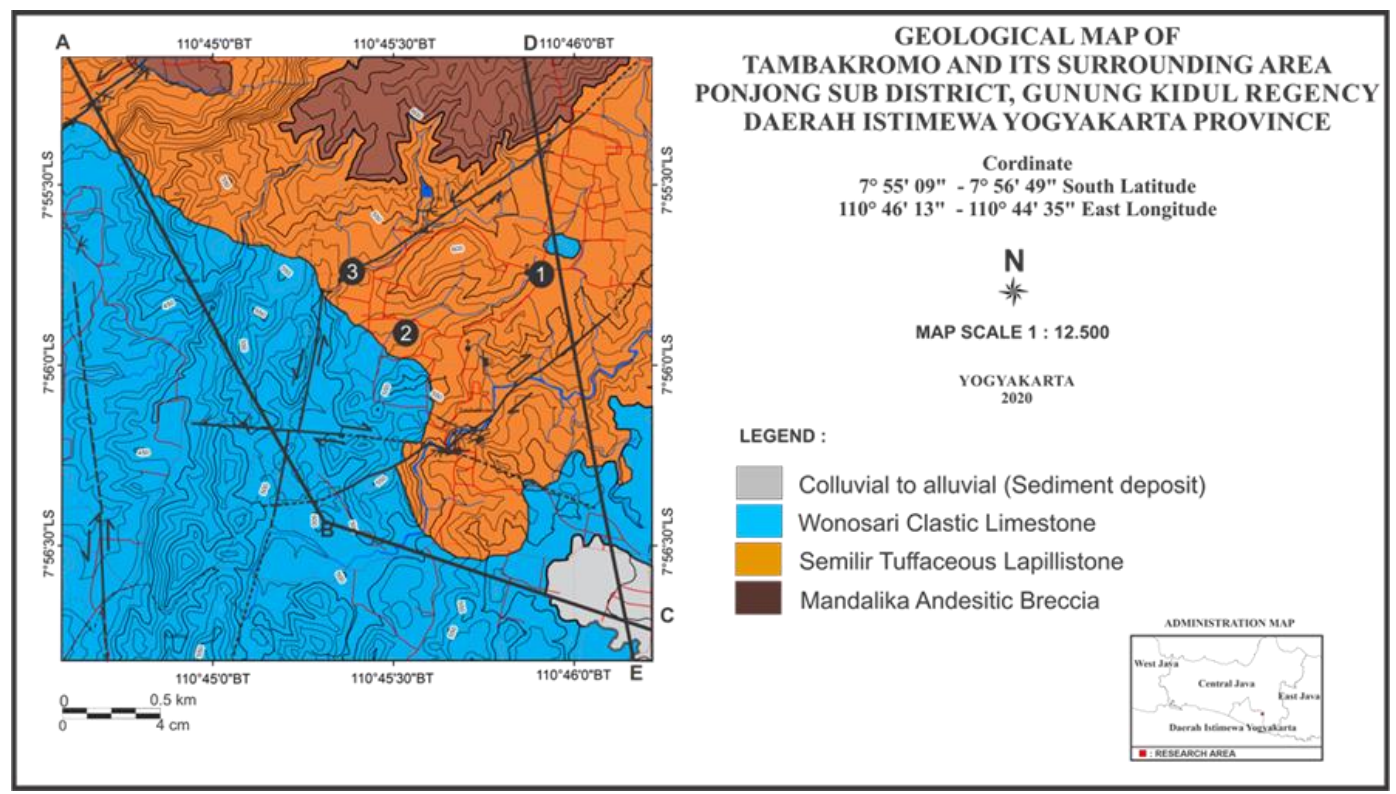

Fig. 9. Presence of Lithology and Structural Geology in Geological Map, Point of Observation 1 (Grogol Village), 2 (Garon Village) and 3 (Sumberejo Village)

The research area is located on border of Panggung Massive Hill and Gunung Sewu Karst. Panggung Massive Hill is located in the northern part of research area. It included in recharge area whereas controlled by variation of rainfall. The rainfall patterns in the Gunung Sewu Karst indicate spatial and temporal variations, according to [22]. The spatial variation depends mainly on elevation and proximity to the sea, while regional climate conditions influence the temporal difference.

Three locations of acquisition geolectrical resistivity (Grogol, Garon, and Sumberejo village) were included in discharge area that were in same direction for electrodes array. East - West direction is chosen because of geological condition such as structural geology in research area. The structural geology like sinistral fault-controlled the presence of springs in Grogol village and the clay alteration in Sumberejo village. The sinistral fault has northeast - southwest direction. On other hand, the northeast - southwest direction of a fault has different kinematics movements, it is dextral fault [23].

Sediment deposit was distributed in each location with thickness of 3 to 5 meters. It was unconsolidated and loose materials. The source of these sediment deposit is interpreted from Semilir or Mandalika Formation [14]. Altered clays are widespread in Garon and Sumberejo village. Meanwhile, there is no altered clay in Grogol village. The thickness of the bedded limestone layer is getting thinner towards the Sumberejo village. Meanwhile, the crystalline limestone rock layer wedge in Garon village.

In the research area, the limestone included a karst topography. The presence of limestone could be aquifer with secondary porosity. The porosity is about 5 to $50 \%$ in karstified limestone [24]. There were some effects of leaching processes such as lapies or vertical hole (ponor). The vertical hole (ponor) indicated there was sinkhole incident in Sawah ombo, Tambakromo, Ponjong [25]. Despite of the limestone is distributed in research area, the surface water would run off to the ground through the ponor. These ponor connects the surface to subsurface water system in karst [26].

Aquifer in research area is interpreted as tuffaceous lapillistone rock layer. These rock layer is getting thinner toward tuffaceous lapillistone rock layer in Sumberejo. Both aquifer in Garon and Sumberejo 
village are included in inter grain aquifer system [27]. It included in confined aquifer meanwhile at Bedoyo, Ponjong the kind of aquifer is unconfined aquifer [15]. The aquifer could be reached at depth in range 50 to 80 meters. However, the local people need to drill the subsurface for aquifer exploitation (Fig. 10).

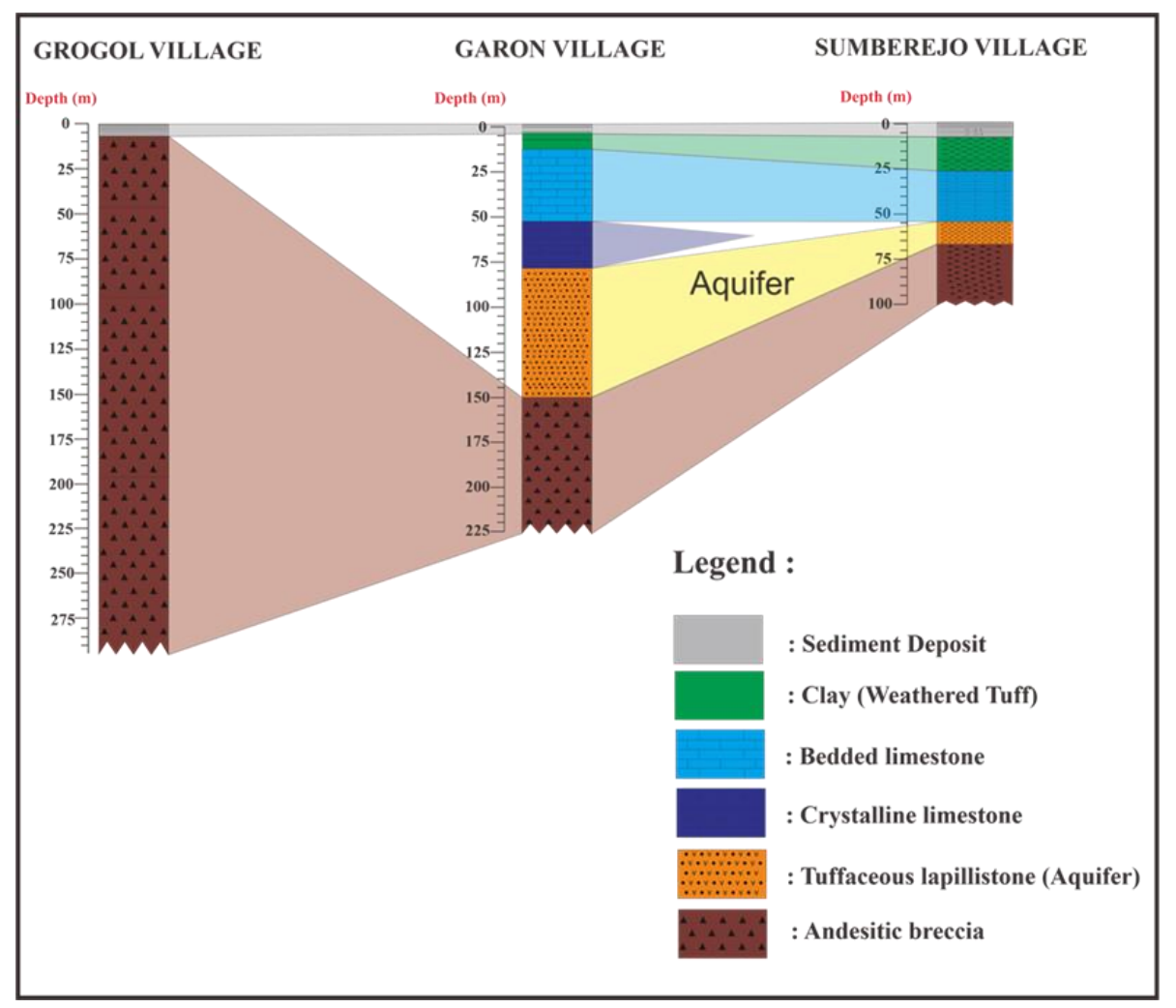

Fig. 10. Correlation of Rock Formation Layer in Research Area, Aquifer Presence in Tuff

\section{CONCLUSION AND SUGGESTION}

The rock formation of subsurface condition at research area is composed by andesitic breccia, tuffaceous lapiilistone, crystalline limestone, bedded limestone, altered clay, and sediment deposit. The aquifer zone is interpreted as Tuffaceous lapillistone with petrographic analysis is composed by glass. The resistivity value of tuffaceous lapillistone is about 43.63 and 340.11 ohmmeters. The tuffaceeous lapillistone could be recognized as aquifer that was located in Garon and Sumberejo village with thickness of 13 to 70 meters at subsurface. Both Garon and Sumberejo village have aquifer zone at a depth of 50 to 80 meters with thickness of 13 to 70 meters. The type of aquifer at research area is included in unconfined aquifer, specific position in between limestone rock layer and andesitic breccia.

On the other side, in Grogol village, there is no presence of aquifer zone based on resistivity data. In this location, resistivity value from the bottom layer to the top layer is more than 10000 ohmmeters. It was an aquifuge in andesitic breccia. This research needs further study about the geochemical of water to determine the quantity and quality of aquifer.

\section{ACKNOWLEDGMENTS}

Authors highly acknowledged to Ristekdikti (DRPM) for funding this research in 2020. Authors also thank to Waskita, Novaldy, Mayang, Dandy, Bella, Basith, and Reynaldo for guiding in field observation. 
Investigation of Aquifer Zone in Tambakromo Village, Ponjong Subdistrict, Gunung Kidul Regency... Al Hussein Flowers Rizqi, Oky Sugarbo

\section{REFERENCES}

[1] Tribun Jogja. (2019). Dua Kabupaten Tetapkan Status Siaga Darurat Kekeringan. Accessed on July $3^{\text {rd }}, 2019$.

[2] Yosaphat, S. E. N. B. W. (2018). Interpretasi Struktur Bawah Permukaan menggunakan Metode Geolistrik Konfigurasi Schlumberger Di Daerah Karst Bribin I, Kecamatan Semanu, Kabupaten Gunungkidul, Yogyakarta. E-Journal Fisika, 7(1): 49-58.

[3] Medcom.id. (2019). 355 Telaga di Gunung Kidul Mengering. Accessed on July 30 ${ }^{\text {th }}, 2019$.

[4] Surono, B. T., \& Sudarno, I. (1992). Peta Geologi Lembar Surakarta-Giritontro, Jawa. Puslitbang Geologi, Bandung.

[5] Sadikin, A. (2013). Pemetaan Alur Sungai Bawah Permukaan Dengan Resistivitas Elektrik Di Daerah Gunungkidul. Jurnal Sumber Daya Air, 9(1): 13-24.

[6] Munandar, Y. K., Massora, M. R., \& Fakhrudin, K. (2017). konfigurasi struktur geologi terhadap geometri akuifer airtanah dengan metode geolistrik schlumberger dan pole-dipole kecamatan gedangsari, kabupaten gunungkidul, diy. metode, 13. METODE, 13, 15.

[7] Redita, D. (2017). Pemetaan Akuifer Airtanah Dan Perhitungan Neraca Air Pada Daerah Karst dengan Menggunakan Metode Geolistrik Schlumberger Di Kabupaten Gunungkidul, Daerah Istimewa Yogyakarta (Doctoral dissertation, UPN" VETERAN" YOGYAKARTA).

[8] Seo, H. P. (2012). Geologi Dan Pengaruh Sebaran Batugamping Terhadap Kondisi Airtanah Berdasarkan Analisa Data Geolistrik Dan Data Pemboran Dusun Sidorejo Dan Sekitarnya, Desa Karang Tengah, Kecamatan Wonosari, Kabupaten Gunung Kidul, Propinsi Di Yogyakarta (Doctoral dissertation, UPN" Veteran" Yogyakarta).

[9] Massora, M. R. (2017). Geologi Dan Kajian Hubungan Struktur Geologi Dan Air Tanah Di Daerah Hargomulyo Dan Sekitarnya, Kecamatan Gedangsari, Kabupaten Gunungkidul, Daerah Istimewa Yogyakarta (Doctoral dissertation, UPN" Veteran" Yogyakarta).

[10] Kompas.com. (2019). Puluhan Ribu Warga di Gunung Kidul Terdampak Kekeringan. Accessed on August $12^{\text {th }}, 2019$.

[11] Bmkg.go.id. (2019). Prakiraan Daerah Potensi Banjir Bulan Agustus, September, dan Oktober 2019. Accessed on August $12^{\text {th }}, 2019$.

[12] Raghunath, H. M. (1987). Ground Water Second Edition. New Delhi: Wiley Eastern Limited.

[13] Halik, G., \& Widodo, J. (2009). Pendugaan potensi air tanah dengan metode geolistrik konfigurasi schlumberger di kampus Tegal Boto Universitas Jember. Media Teknik Sipil, 8(2): 109-114.

[14] Waskita, R. S. A., \& Wijayanti, H. K. (2020). Studi Provenance Dan Analisis Granulometri Endapan Pasir Di Daerah Tambakromo, Ponjong, Gunung Kidul, Daerah Istimewa Yogyakarta. Geoda, 1(1): 35-49.

[15] Uligawati, G. W., \& Fatimah, F. (2020). Identifikasi Akuifer Dengan Metode Geolistrik Konfigurasi Schlumberger Di Daerah Ponjong, Gunung Kidul. Geoda, 1(1): 1-7.

[16] Dengen, N. (2016). Pengolahan Data Geolistrik Pada Ekplorasi Sumber Air Tanah Di Kecamatan Kongbeng Kabupaten Kutai Timur Dengan Perangkat Lunak RES2DINV. Informatika Mulawarman: Jurnal Ilmiah Ilmu Komputer, 7(1): 27-34.

[17] Bisri, M. (2012). Air Tanah; Studi Tentang Pendugaan Air Tanah, Sumur Air Tanah dan Upaya Dalam Konsevasi Air Tanah.

[18] Schmid, R. (1981). Descriptive nomenclature and classification of pyroclastic deposits and fragments: Recommendations of the IUGS Subcommission on the Systematics of Igneous Rocks. Geology, 9(1): 41-43.

[19] Kodoatie, R. J. (2012). Tata Ruang Air Tanah. Penerbit Andi.

[20] Corbett, G. J., \& Leach, T. M. (1998). Southwest Pacific Rim gold-copper systems: structure, alteration, and mineralization (No. 6). Littleton, Colorado: Society of Economic Geologists

[21] Al Hussein Flowers Rizqi, O. S. Rekonstruksi Stratigrafi Jalur Sungai Krenceng, Ponjong, Gunung Kidul, Yogyakarta.

[22] Brunsch, A., Adji, T. N., Stoffel, D., Ikhwan, M., Oberle, P., \& Nestmann, F. (2011). 
JIPF, Vol. 6 No. 3, September 2021

Hydrological assessment of a karst area in Southern Java with respect to climate phenomena. In Proceeding of Asian Trans-Disciplinary Karst Conference, Yogyakarta.

[23] Rizqi, A. H. F. (2018). Identifikasi Struktur Geologi Sungai Watugajah, Kec. Gedangsari, Kab. Gunung Kidul, DIY. Available at: http://journal.itny.ac.id/index.php/ReTII/article/view/1004 (Accessed: 3October2020).

[24] Acworth, R. I. (2001). Electrical Methods in Groundwater Studies, Short Course Note. University of New South Wales, School of Civil and Environmental Engineering.

[25] Song, K. I., Cho, G. C., \& Chang, S. B. (2012). Identification, remediation, and analysis of karst sinkholes in the longest railroad tunnel in South Korea. Engineering Geology, 135: 92-105.

[26] Matius, P., Rahmadi, D., Setiawan, D., \& Mt, D. (2016). Pedoman Praktis Survey Terintegrasi Kawasan Karst.

[27] Sari, A. S., Bahagiarti, S., Suharsono, S., \& Prasetyadi, C. (2020). Groundwater quality in Ponjong Karst, Gunungkidul Regency, Special Region of Yogyakarta. Journal of Earth and Marine Technology (JEMT), 1(1): 7-11. 